Images in...

\title{
The lack of sleep, the pineal gland and breast cancer
}

Madhup Rastogi, Manoj Kumar Gupta, Swaroop Revannasiddaiah, Rajeev Kumar Seam

Department of Radiotherapy \& Oncology, Regional Cancer Centre, Indira Gandhi Medical College, Shimla, Himachal Pradesh, India

Correspondence to Dr Swaroop Revannasiddaiah, swarooptheone@gmail.com

\section{DESCRIPTION}

A 57-year-old woman reported a 'decreased ability to sleep' for the past 6 months, adding that she had never suffered from insomnia earlier. She also suffered from a few additional symptoms: fatigue, irritability and an occasional 'headache' all of which she attributed to be resultant of her reduced ability to sleep. However, when she had a sudden onset of blurred vision and vomiting for the past 1 month, she visited her physician. Her history was significant for having been treated 9 years ago for $\mathrm{T}_{1} \mathrm{~N}_{0} \mathrm{M}_{0}$-staged breast cancer, with breastconservation surgery, radiotherapy and adjuvant tamoxifen for 5 years.

MRI revealed a mass lesion (measuring $2.3 \mathrm{~cm}$ in its greatest diameter) occupying the region of the pineal gland (figure 1). This was hypointense/isointense on fluid attenuated inversion recovery, T1-weighted and T2-weighted images in comparison with grey-matter, with intense heterogeneous postcontrast enhancement. There appeared to be obstructive hydrocephalus-with dilated third and lateral ventricles (figure 2). An image-guided stereotactic biopsy confirmed metastaticcarcinoma, which was positive for oestrogen and progesterone receptors.
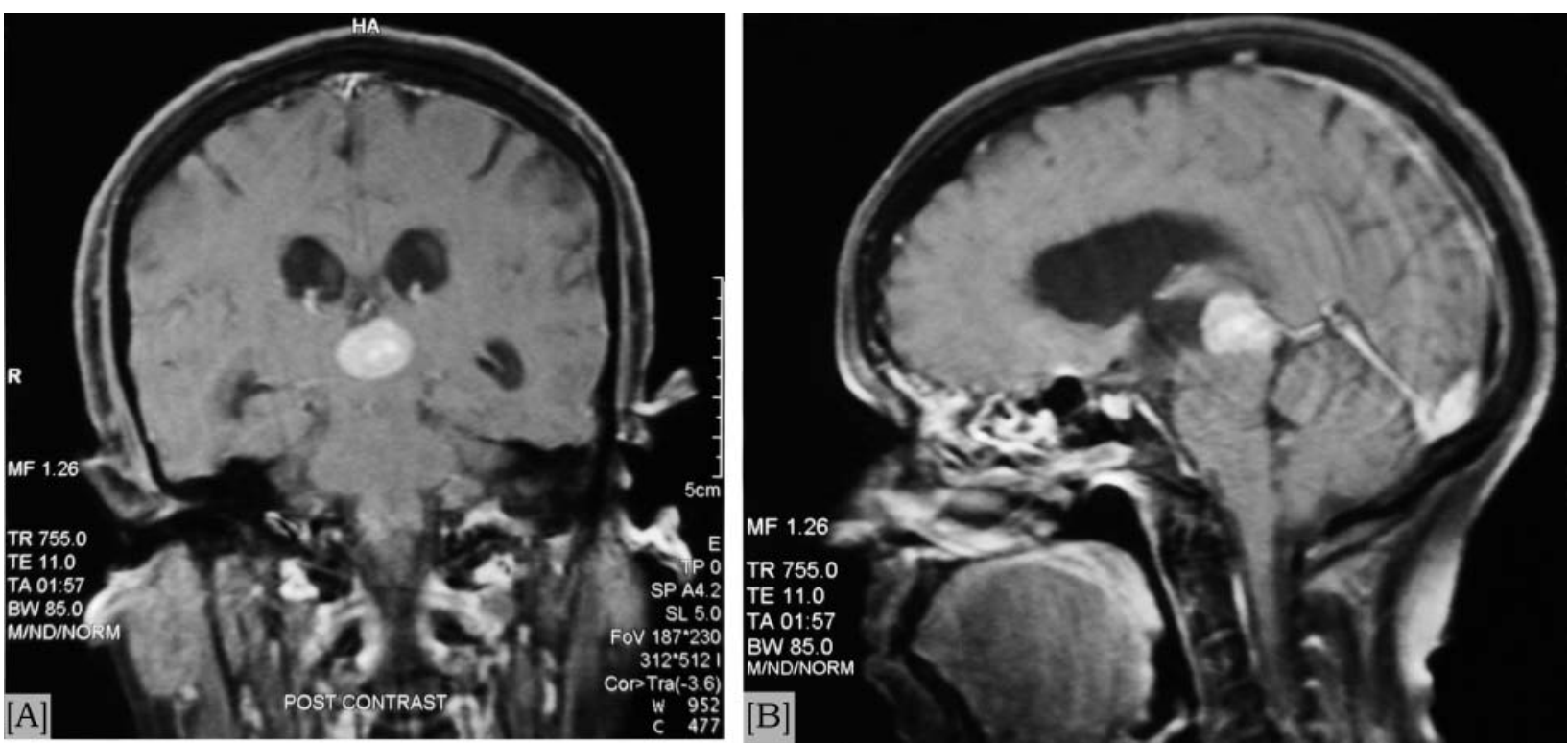

Figure 1 Coronal $(A)$ and sagittal $(B)$ contrast-enhanced T1-weighted MRI showing an enhanced mass lesions in the pineal gland region. 


\section{BMJ Case Reports}

\section{Learning points}

- Even among patients treated for early-stage breast carcinoma, there indeed exists a risk of late distant relapse, and the importance of continued follow-up among asymptomatic patients is paramount. ${ }^{1}$

- Metastases to the pineal gland are a rare phenomenon. ${ }^{2}$ Stereotactic biopsy is a feasible option to establish histopathology among patients with pineal gland mass lesions.

- Annual follow-up of patients treated for breast cancer is to be continued indefinitely, since it offers not only an opportunity to examine the patient with regard to breast cancer but also a chance to monitor the side effects of long-term hormonal manipulation, which include a higher-risk of osteoporosis and an increased risk of endometrial carcinoma.
Contributor MR decided to publish the case, provided the images and took patient consent. MKG and SR wrote the article. RKS revised the article and set the image quiz questions.

Competing interests None.

Patient consent Obtained.

\section{REFERENCES}

1. Early Breast Cancer Trialists' Collaborative Group. Systemic treatment of early breast cancer by hormonal, cytotoxic, or immune therapy. 133 randomised trials involving 31000 recurrences and 24000 deaths among 75000 women. Early Breast Cancer Trialists' Collaborative Group. Lancet 1992;339:1-15.

2. Lassman $\mathbf{A B}$, Bruce JN, Fetell MR. Metastases to the pineal gland. Neurology 2006;67:1303-4.

This pdf has been created automatically from the final edited text and images.

Copyright 2012 BMJ Publishing Group. All rights reserved. For permission to reuse any of this content visit http://group.bmj.com/group/rights-licensing/permissions.

BMJ Case Report Fellows may re-use this article for personal use and teaching without any further permission.

Please cite this article as follows (you will need to access the article online to obtain the date of publication).

Rastogi M, Gupta MK, Revannasiddaiah S, Seam RK. The lack of sleep, the pineal gland and breast cancer. BMJ Case Reports 2012;10.1136/bcr-2012-006763, Published XXX

Become a Fellow of BMJ Case Reports today and you can:

- Submit as many cases as you like

- Enjoy fast sympathetic peer review and rapid publication of accepted articles

- Access all the published articles

- Re-use any of the published material for personal use and teaching without further permission

For information on Institutional Fellowships contact consortiasales@bmigroup.com

Visit casereports.bmj.com for more articles like this and to become a Fellow 